\title{
The Apocrine Profile of Triple-negative Breast Carcinomas in Patients Aged 45 Years or Younger: favorable but rare features
}

\section{Perfil apócrino em carcinomas mamários triplo- negativos de pacientes até 45 anos: característica favorável, ainda que rara}

\author{
Sergio Mitsuo Masili-Oku ${ }^{1,2}$ Carlos Eduardo Bacchi ${ }^{3}$ \\ Edmund C. Baracat ${ }^{4}$ Filomena Marino Carvalho ${ }^{1}$ \\ ${ }^{1}$ Departament of Pathology, Faculdade de Medicina da Universidade \\ de São Paulo, São Paulo, SP, Brazil \\ 2 Instituto do Câncer do Estado de São Paulo (ICESP), Hospital das \\ Clínicas da Faculdade de Medicina da Universidade de São Paulo, São \\ Paulo, SP, Brazil \\ ${ }^{3}$ Consultoria em Patologia, Botucatu, SP, Brazil \\ ${ }^{4}$ Gynecology Discipline, Department of Gynecology and Obstetrics, \\ Hospital das Clínicas da Faculdade de Medicina da Universidade de \\ São Paulo, São Paulo, SP, Brazil
}

Felipe Seabra Fernandes ${ }^{1}$ José Roberto Filassi ${ }^{2}$

Address for correspondence Filomena M. Carvalho, MD, PhD, Departament of Pathology, Faculdade de Medicina da Universidade de São Paulo, Av. Dr. Arnaldo 455-sala 1149, 01246-903, São Paulo, SP. Brazil (e-mail: filomena@usp.br).

Rev Bras Ginecol Obstet 2016;38:512-517.

\author{
Abstract \\ Keywords \\ - breast cancer \\ - triple-negative \\ - apocrine \\ - immunohisto- \\ chemistry \\ - androgen receptor \\ - epidermal growth \\ factor receptor $\mathrm{K}_{\mathrm{i}}-67$
}

Objective Triple-negative breast carcinomas (TNBCs) represent a heterogeneous group of neoplasias, even though they generally exhibit a clinically more aggressive phenotype, and are more prevalent in young women. To date, targeted therapies for this group of tumors have not been defined. The aim of this study was to evaluate the frequency of the apocrine subtype in TBNCs from premenopausal patients as defined by the immunohistochemical expression of the androgen receptor (AR) and its association with: histological type; tumor grade; proliferative activity; epidermal growth factor receptor (EGFR) expression; and a basal-like phenotype.

Methods A total of 118 tumor samples from patients aged 45 years or younger were selected and reviewed according to histological type and grade. $\mathrm{K}_{\mathrm{i}}-67$ expression was also evaluated. Immunohistochemical expression of the AR, basal cytokeratin $5 / 6$, and EGFR expression were analyzed in tissue microarrays. The apocrine subset was defined by AR-positive expression. The basal-like phenotype was characterized by cytokeratin $5 / 6$ and/or EGFR expression.

Results An apocrine profile was identified in 6/118 (5.1\%) cases. This subset of cases also exhibited a lower rate of $\mathrm{K}_{\mathrm{i}}-67$ expression (17.5\% versus $70.0 \%, p=0.02$ ), and a trend toward a lower histological grade (66.7\% versus $27.9 \%, p=0.06$ ). received

May 1, 2016

accepted

September 20, 2016

published online

November 3, 2016
DOI http://dx.doi.org/

$10.1055 / \mathrm{s}-0036-1593854$. ISSN 0100-7203.
Copyright $\odot 2016$ by Thieme Publicações License terms Ltda, Rio de Janeiro, Brazil
()(1) $\Theta \circledast$ 


\section{Resumo}

\author{
Palavras-chave \\ - câncer de mama \\ - triplo-negativo \\ - apócrino \\ - imuno- \\ histoquímica \\ - receptor de \\ androgênio \\ - receptor do fator \\ de crescimento \\ epidérmico \\ - $\mathrm{K}_{\mathrm{i}}-67$
}

Conclusions The apocrine subtype of TNBCs is rare among premenopausal women, and it tends to present as carcinomas of lower grade and lower proliferative activity, suggesting a less aggressive biological phenotype.

Objetivo Carcinomas mamários triplo-negativos representam um grupo heterogêneo de neoplasias, embora geralmente exibam fenótipo clinicamente mais agressivo e sejam mais prevalentes em mulheres jovens. Até o presente, terapias-alvo para esses grupos não foram definidas. O objetivo deste estudo foi avaliar a frequência do subtipo apócrino em carcinomas mamários triplo-negativos de mulheres na pré-menopausa, definido pela expressão imuno-histoquímica do receptor de androgênio, e sua associação com tipo histológico, grau histológico, atividade proliferativa, expressão do receptor do fator de crescimento epidérmico (EGFR) e o fenótipo basal-símile.

Métodos Foram selecionadas 118 amostras de tecido tumoral de pacientes com até 45 anos de idade. As amostras foram revisadas quanto a tipo e grau histológicos e expressão do $\mathrm{K}_{\mathrm{i}}-67$. A expressão imuno-histoquímica de receptor de androgênio, citoqueratina basal 5/6, e do EGFR foram analisadas em amostras de microarranjos de tecido. $O$ subtipo apócrino foi definido pela positividade do receptor de androgênio. $O$ fenótipo basal-símile foi caracterizado pela expressão da citoqueratina $5 / 6$ e/ou do EGFR. Resultados O perfil apócrino foi identificado em 6/118 (5,1\%) casos. Este subgrupo apresentou menor fração de expressão do $\mathrm{K}_{\mathrm{i}}-67(17,5 \%$ versus $70,0 \%, p=0,02)$ e uma tendência a menor grau histológico $(66,7 \%$ versus $27,9 \%, p=0,06)$.

Conclusões O subtipo apócrino dos carcinomas mamários triplo-negativos é raro em mulheres na pré-menopausa, e tende a se apresentar como carcinomas de menor grau e menor atividade proliferativa, sugerindo fenótipo biológico menos agressivo.

\section{Introduction}

Current knowledge: triple-negative breast carcinomas (TNBCs) are, generally, very aggressive neoplasms, more prevalent in young women, with no target for therapy. They proved to be heterogeneous regarding morphology, response to chemotherapy, and genomic changes. There is no doubt that potential targets will work only in subsets of TNBCs. The candidates for these subsets are BRCA-1 mutant, BRCA1-like tumors with underlying defects in homologous recombination-mediated DNA repair, and androgen-receptor positive tumors. In this study, we selected 118 consecutive premenopausal patients with TNBCs to examine the frequency of the apocrine profile defined by the immunohistochemical expression of the androgen receptor (AR), which can be performed in diagnostic routine. Apocrine TNBCs were rare in this population; however, our findings support a more favorable biology of these tumors based on lower proliferative activity and lower tumor grade.

Triple-negative breast carcinomas correspond to a heterogeneous group of neoplasias that usually exhibits a clinically more aggressive phenotype. Triple-negative breast carcinomas commonly exhibit a lack of estrogen and progesterone receptor expression, as well as an absence of overexpression and/or amplification of the epidermal growth factor receptor (EGFR), HER2. Currently there is no targeted therapy for them. Triple-negative breast carcinomas are also more prevalent in young patients. ${ }^{1,2}$ While TNBCs are often associated with a basal-like genetic phenotype, $21.4 \%$ of them correspond to other molecular types, such as HER2-enriched (7.8\%), normal (7.0\%), luminal B (4.4\%), and luminal A (2.2\%). ${ }^{3}$ Initially, the basal-like phenotype of TNBCs was defined by the immunohistochemical expression of basal cytokeratin $5 / 6$ and/or EGFR. ${ }^{4,5}$ Other definitions have been proposed, but none have exhibited sufficient concordance with gene expression profiles, consistent with the heterogeneity of the TNBC phenotype. ${ }^{6}$ Actually, gene expression-based molecular analyses have identified distinct subgroups of TNBCs, such as claudinlow, immunomodulatory, mesenchymal-like, mesenchymal stem cell-like, androgen luminal, and basal-like types 1 and 2. ${ }^{7}$ Moreover, the immunohistochemical profiles corresponding to these types are actively being studied. ${ }^{4,6,7}$ Among the currently identified phenotypes, the best characterized, either by genetic and/or immunohistochemical approaches, is the apocrine-based phenotype, which involves the expression of the AR. ${ }^{7-9}$ Correspondingly, the AR represents a promising therapeutic target for this carcinoma subtype. ${ }^{10}$

The aim of the present study was to analyze the molecular apocrine profile of TNBCs that were biopsied in women 45 years or younger.

\section{Methods}

\section{Institutional Approval}

This project was approved by the Scientific Committee of the Department of Pathology and by the Ethical Committee for 
514 Apocrine Profile of TNBCs in Patients under 45 Years Old Masili-Oku et al.

Table 1 Reagents and methods used for the immunohistochemical analyses performed

\begin{tabular}{|l|l|l|l|l|}
\hline Antigen & Clone & Source & Dilution & Epitope retrieval method \\
\hline AR & F39.44.1 & $\begin{array}{l}\text { BlOGenex } \\
\text { (Fremont, USA) }\end{array}$ & $\begin{array}{l}\text { Tris-EDTA buffer (pH 9.0) } \\
20 \text { minutes, 97 } \mathrm{C}\end{array}$ \\
\hline $\mathrm{K}_{\mathrm{i}-67}$ & Mouse, MIB-1 & $\begin{array}{l}\text { Dako } \\
\text { (Glostrup, Denmark) }\end{array}$ & $\begin{array}{l}\text { Citrate buffer (pH 6.1) } \\
20 \text { minutes, 97 } \mathrm{C}\end{array}$ \\
\hline Cytokeratin 5/6 & D5/16B4 & $\begin{array}{l}\text { Dako } \\
\text { (Glostrup, Denmark) }\end{array}$ & $\begin{array}{l}\text { Tris-EDTA buffer (pH 9.0) } \\
20 \text { minutes, 97 C }\end{array}$ \\
\hline EGFR & $31 \mathrm{G} 7$ & $\begin{array}{l}\text { Zymed } \\
\text { (South San Francisco) }\end{array}$ & $1: 100$ & $\begin{array}{l}\text { Citrate buffer (pH 6.1) } \\
20 \text { minutes, 97 } \mathrm{C}\end{array}$ \\
\hline
\end{tabular}

Abbreviations: AR, androgen receptor; EGFR, epidermal growth factor receptor.

Research Projects of the Hospital das Clínicas da Faculdade de Medicina da Universidade de São Paulo, Brazil (CAPPesq) (protocol n. 311/10). As the study was retrospective, informed patient consent was waived, and any form of patient identification was abolished.

\section{Selection of Cases}

Formalin-fixed, paraffin-embedded tissue specimens from 118 patients aged 45 years or younger with triple-negative primary breast carcinomas diagnosed between July 2009 and March 2011 that corresponded with consecutive cases with available paraffin blocks from our larger previous study were selected. ${ }^{11}$ In the previous study, samples from 5,687 consecutive patients were sent to the Consultoria em Patologia, a private reference surgical pathology laboratory, for routine predictive and prognostic immunohistochemical profiling. Triple-negative breast carcinomas corresponded to $15.7 \%$ $(894 / 5,687)$ of all breast cancer diagnosis. In the subgroup composed by 1,386 patients aged 45 years or younger, the number of TNBCs raised to $19.5 \%(271 / 1,386)$. From the latter, 130 of the more recent cases that had paraffin block specimens available were selected for the present study.

\section{Pathological Study}

The same pathologist (FMC) reviewed all of the slides and evaluated their histological subtypes based on World Health Organization criteria. ${ }^{12}$ Tumor grading was assigned according to the Nottingham criteria. ${ }^{13}$ The following characteristics were also evaluated: microscopic tumor contour (total, partially circumscribed, or infiltrative); fraction of necrosis (absent, focal, or extensive); in situ component (absent, $<25 \%$, or $>25 \%$ ); any tubule formation (yes or no); lymphocytic stromal infiltration (absent/slight or moderate/intense); desmoplastic intratumoral reaction (absent/ discrete or moderate/intense); vascular embolization; and percentage of $\mathrm{K}_{\mathrm{i}}-67$ expression. A representative area of each tumor was selected for the construction of tissue microarray (TMA) blocks.

\section{TMA Construction}

Tissue sections were stained with hematoxylin/eosin, and the corresponding sections in each paraffin donor block were marked. Then, one cylinder of material (2.0 $\mathrm{mm}$ in diameter) was taken from each of these regions, and they were mounted into recipient paraffin blocks at $2 \mathrm{~mm}$ intervals using a precision microarray instrument (Beecher Instruments, Silver Spring, MD, US). A grid system was established so that each core had an $\mathrm{x}$ - and $\mathrm{y}$-coordinate reference for sample identification. The blocks were sealed at $60^{\circ} \mathrm{C}$ for 10 minutes. Sections ( $3 \mu \mathrm{m}$ ) from each TMA block were prepared using standard techniques, and were mounted on Starfrost ${ }^{\circledR}$ (Light Labs, Dallas, TX, US) slides. The first histological sections that were cut were stained with hematoxylin/eosin to ensure that the appropriate sections of the tumor had been obtained.

\section{Immunohistochemistry and Scoring}

Epitope retrieval methods and the source and dilution of the antibodies used are listed in -Table 1. Bound antibodies were detected with horseradish peroxidase labeled polymers conjugated to goat anti-rabbit or goat anti-mouse immunoglobulins (DAKO EnVisionTM System, US). Peroxidase activity was visualized with diaminobenzidine staining (DAKO).

Androgen receptor expression was evaluated based on the percentage of cells that exhibited positive nuclear staining in a sample (-Fig. 1). Positive EGFR expression was defined

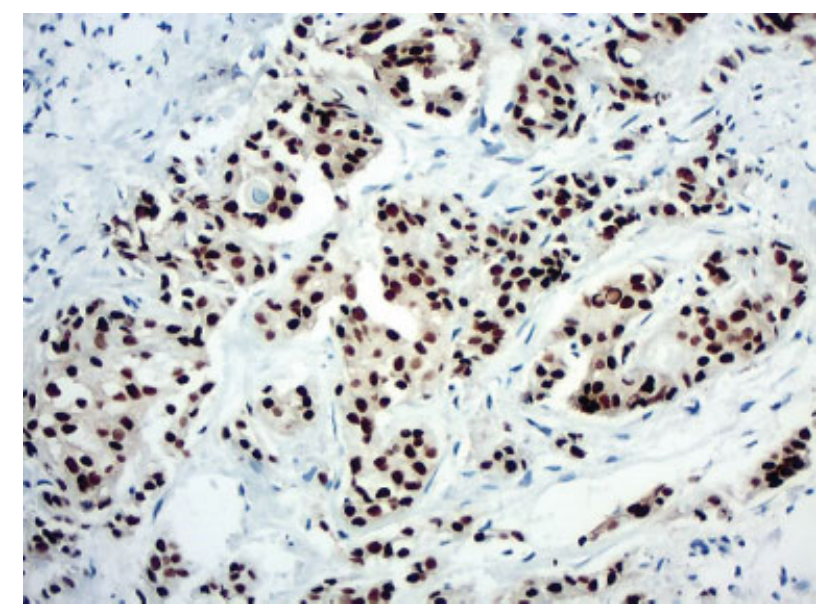

Fig. 1 Representative image of a breast carcinoma stained for AR expression with nuclear immunostaining (original magnification, $200 \times)$. 
based on the presence of complete or moderate/strong membrane staining in $\geq 10 \%$ of cells. For cytokeratin $5 / 6$, any cytoplasmic staining of moderate to strong intensity in at least $1 \%$ of cells was considered positive. The apocrine subtype was defined by the expression of the AR. All of the cases presented with at least $80 \%$ AR-positive cells; therefore, no cut-off was defined for the AR staining. A basal-like phenotype was defined by the expression of cytokeratin $5 / 6$ and/or EGFR. ${ }^{4}$

\section{Statistical Analyses}

Statistical analyses were performed using SPSS software, version 22.0 (SPSS, Chicago, IL, US). The features of the apocrine and non-apocrine subgroups of the TNBCs were described and compared using Fisher's exact test (for categorical variables) or the Mann-Whitney test (for patient age and $\left.\mathrm{K}_{\mathrm{i}}-67\right)$. A $p$-value lower than 0.05 was considered significant.

\section{Results}

The clinicopathological features of all of the examined cases are summarized in - Table 2. An apocrine subset was detected in 6/118 (5.1\%) of the TNBC tissues examined. The median patient age for the apocrine samples versus the nonapocrine samples was 41 and 39 years respectively, and this difference was not significant. Apocrine tumors also presented a lower rate of $\mathrm{K}_{\mathrm{i}}-67$ expression (17.5\% versus $70.0 \%$, $p=0.02$ ), and a trend toward a lower histological grade (66.7\% versus $27.9 \%, p=0.06$ ). None of the other studied variables were found to significantly differ between the two groups.

\section{Discussion}

Triple-negative breast carcinomas represent a very heterogeneous group of breast cancers that have a poor prognosis and no targeted therapy available. ${ }^{14}$ Most TNBCs exhibit a basal-like molecular subtype, and have been identified at a higher frequency in women carrying BRCA1. ${ }^{15}$ An important association has been observed between TNBCs, basal-like carcinomas, and BRCA1-associated carcinomas, even though they are not synonymous. In this study, we defined the basallike phenotype by the immunoexpression of EGFR and/or cytokeratin $5 / 6$, according to the criteria of Nielsen et al. ${ }^{4}$ Eighty-seven $(73.7 \%)$ of our 118 cases presented the basallike phenotype, which was consistent with the rate of cases of previous studies. ${ }^{16,17}$ The basal-like phenotype was present in 5 out of $6(95.6 \%)$ cases with apocrine phenotype and in 82 out of 112 (73.2\%) cases within the non-apocrine group. However, this difference was not significant, probably because of the small number of apocrine cases. The coexistence

Table 2 Clinicopathological features of TNBCs from 118 patients aged 45 years or younger

\begin{tabular}{|c|c|c|c|c|}
\hline Features & Apocrine & Non-apocrine & $\mathrm{N}$ & $P$ \\
\hline Number of cases (\%) & $6(5.1 \%)$ & 112 (94.9\%) & 118 & \\
\hline Mean age \pm SD, years & 41 & 39 & 118 & $0.2940^{*}$ \\
\hline \multicolumn{5}{|l|}{ Histological grade } \\
\hline $1 / 2$ & $4(66.7 \%)$ & $31(27.9 \%)$ & 35 & $0.0646 \dagger$ \\
\hline 3 & $2(33.3 \%)$ & $80(72.1 \%)$ & 82 & \\
\hline Not assessed & 0 & 1 & 1 & \\
\hline \multicolumn{5}{|l|}{ Basal-like phenotype } \\
\hline Yes & $5(95.6 \%)$ & $82(73.2 \%)$ & 87 & $1.0000 \dagger$ \\
\hline No & $1(4.4 \%)$ & $30(26.8 \%)$ & 31 & \\
\hline \multicolumn{5}{|l|}{ EGFR expression } \\
\hline Yes & $3(50 \%)$ & $59(52.7 \%)$ & 62 & $1.0000 \dagger$ \\
\hline No & $3(50 \%)$ & $53(47.3 \%)$ & 56 & \\
\hline $\mathrm{K}_{\mathrm{i}}-67$, mean $\pm \mathrm{SD}$ & 17.5 & 70 & 118 & $0.0199^{*}$ \\
\hline \multicolumn{5}{|l|}{ Lymphatic invasion } \\
\hline Yes & $3(60 \%)$ & $34(31.7 \%)$ & 37 & $0.3295 \dagger$ \\
\hline No & $2(40 \%)$ & $73(68.3 \%)$ & 75 & \\
\hline Not assessed & 1 & 5 & 6 & \\
\hline \multicolumn{5}{|l|}{ Tumor necrosis } \\
\hline Yes & $3(50 \%)$ & $76(67.8 \%)$ & 79 & $0.3953 \dagger$ \\
\hline No & $3(50 \%)$ & $36(32.2 \%)$ & 39 & \\
\hline
\end{tabular}

Abbreviations: EGFR, epidermal growth factor receptor; SD, standard deviation; TNBC, triple-negative breast carcinoma. †Fisher's exact test; ${ }^{*}$ MannWhitney test. 
of apocrine and basal-like phenotypes was also described by Choi et al. ${ }^{8}$ These authors studied the immunohistochemical profile of 122 TNBCs, and found the molecular apocrine phenotype in $12(9.8 \%)$ of the cases, the mixed apocrine and basal-like in 5 (4.1\%), and the apocrine plus claudin-low in $6(4.9 \%)$ cases. Although their number of apocrine cases was higher than ours, they included older patients ( $47.5 \pm 12.1$ years), and the mean age of the apocrine type was even higher $(56.9 \pm 13.7$ years $) .{ }^{8}$ The present set of samples was restricted based on younger patients to include a higher percentage of TNBC cases, albeit with a lower frequency of AR expression ${ }^{1,8,18}$. For example, AR expression was previously detected in $12 \%$ of TNBCs, ${ }^{10}$ while only $5.1 \%$ of the TNBCs examined in the present study were found to express the AR. Another study found AR expression in $17.7 \%$ (87/492) of TNBCs, and the mean age of patients with ARpositive was higher than those with AR-negative tumors (53 years versus 47 years, $p<0.001) .^{18}$ They also observed a significant correlation between AR expression and lower grade tumors. However, they could not explain the worse prognosis they observed in the apocrine group, which differed from the literature. ${ }^{18}$ The results of our study are consistent with previous observations, despite the limited number of apocrine carcinomas that were examined $(n=6)^{8,19}$

Efforts to identify subtypes of TNBCs according to predictive variables have been described in recent studies of basallike carcinomas and/or TNBCs. ${ }^{7,20}$ Less than $30 \%$ of women with metastatic triple-negative carcinomas survive more than 5 years, and most do not survive regardless of the chemotherapy regimens they undergo. ${ }^{21}$ However, it has been reported that basal-like carcinomas are more sensitive to platinum-based therapies, ${ }^{20}$ and drugs acting as poly ADP ribose polymerase (PARP) inhibitors may be effective for the treatment of BRCA1-associated carcinomas once the DNA repair process in these tumors is defective. ${ }^{22}$ Heretofore, there is a lack of specific and effective therapies for TNBCs. Therefore, a possible role for the AR in defining a distinct subtype of TNBC is of interest. ${ }^{7,8,23}$ The biological and therapeutic applications of the AR have been widely characterized for prostate cancers, but fewer studies have investigated the role of the AR in breast cancer. ${ }^{24}$ It is also possible that other molecular events may be involved, such as those involving the microenvironment and epigenetic phenomena.

Previously we demonstrated that AR expression in HER2 carcinomas is associated with lower proliferative activity and lower tumor grade, thereby suggesting a less aggressive tumor behavior. ${ }^{25}$ Mrklić et $\mathrm{al}^{26}$ also observed an inverse correlation between the $\mathrm{K}_{\mathrm{i}}-67$ index and the AR status for TNBC, which suggests a possible antiproliferative effect of androgens.

Other studies have analyzed the relationship between AR immunohistochemistry and tumor clinicopathological features, and an inverse relationship between AR expression and a higher clinical stage, a higher histological grade, and a higher mitotic score was observed. ${ }^{19,25}$ These data suggest that AR-positive TNBCs may be less aggressive tumors. In addition, AR expression appears to predict responses to anti- androgen therapies. For example, in the phase II study conducted by Gucalp et al ${ }^{10}$ with AR-positive, metastatic TNBCs, the clinical benefit rate associated with the antagonist, bicalutamide (150 mg/day), was of $12 \%$.

In spite of the limitations of this study concerning the small number of apocrine cases and the absence of follow-up information, we could confirm the low frequency of the apocrine profile among premenopausal patients and its association with lower grade and lower proliferative activity. Our results reinforce the heterogeneity of TNBCs, a group of different neoplasias that only have in common the absence of estrogen and progesterone receptors, and HER2.

\section{Conclusion}

Despite the small number of cases that were analyzed, the present results suggest that the apocrine subgroup of TNBCs is less frequent in premenopausal patients. This subgroup also tends to present as carcinomas of lower grade and lower proliferative activity, which is consistent with a less aggressive biological behavior. These results can be considered in strategies for the development of targeted therapies for TNBCs.

This study was supported by the São Paulo Research Foundation (FAPESP) (Process n. 2014/15472-8).

\section{References}

1 Carvalho FM, Bacchi LM, Santos PP, Bacchi CE. Triple-negative breast carcinomas are a heterogeneous entity that differs between young and old patients. Clinics (Sao Paulo) 2010;65(10): 1033-1036

2 Malorni L, Shetty PB, De Angelis C, et al. Clinical and biologic features of triple-negative breast cancers in a large cohort of patients with long-term follow-up. Breast Cancer Res Treat 2012; 136(3):795-804

3 Prat A, Adamo B, Cheang MC, Anders CK, Carey LA, Perou CM. Molecular characterization of basal-like and non-basal-like triple-negative breast cancer. Oncologist 2013;18(2):123-133

4 Nielsen TO, Hsu FD, Jensen K, et al. Immunohistochemical and clinical characterization of the basal-like subtype of invasive breast carcinoma. Clin Cancer Res 2004;10(16):5367-5374

5 Yamamoto Y, Ibusuki M, Nakano M, Kawasoe T, Hiki R, Iwase H. Clinical significance of basal-like subtype in triple-negative breast cancer. Breast Cancer 2009;16(4):260-267

6 Prat A, Parker JS, Karginova O, et al. Phenotypic and molecular characterization of the claudin-low intrinsic subtype of breast cancer. Breast Cancer Res 2010;12(5):R68

7 Lehmann BD, Bauer JA, Chen X, et al. Identification of human triplenegative breast cancer subtypes and preclinical models for selection of targeted therapies. J Clin Invest 2011;121(7):2750-2767

8 Choi J, Jung WH, Koo JS. Clinicopathologic features of molecular subtypes of triple negative breast cancer based on immunohistochemical markers. Histol Histopathol 2012;27(11):1481-1493

9 McNamara KM, Yoda T, Takagi K, Miki Y, Suzuki T, Sasano H. Androgen receptor in triple negative breast cancer. J Steroid Biochem Mol Biol 2013;133:66-76

10 Gucalp A, Tolaney S, Isakoff SJ, et al; Translational Breast Cancer Research Consortium (TBCRC 011). Phase II trial of bicalutamide in patients with androgen receptor-positive, estrogen receptornegative metastatic Breast Cancer. Clin Cancer Res 2013;19(19): 5505-5512 
11 Carvalho FM, Bacchi LM, Pincerato KM, Van de Rijn M, Bacchi CE. Geographic differences in the distribution of molecular subtypes of breast cancer in Brazil. BMC Womens Health 2014;14:102

12 Lakhani SR, Ellis IO, Schnitt SJ, Tan PH, van de Vijver MJ. WHO classification of tumours of the breast. 4th ed. Paris: IARC; 2012

13 Elston CW, Ellis IO. Pathological prognostic factors in breast cancer. I. The value of histological grade in breast cancer: experience from a large study with long-term follow-up. Histopathology 1991;19(5):403-410

14 Gluz O, Liedtke C, Gottschalk N, Pusztai L, Nitz U, Harbeck N. Triple-negative breast cancer-current status and future directions. Ann Oncol 2009;20(12):1913-1927

15 Haffty BG, Yang Q, Reiss M, et al. Locoregional relapse and distant metastasis in conservatively managed triple negative early-stage breast cancer. J Clin Oncol 2006;24(36):5652-5657

16 Thike AA, Iqbal J, Cheok PY, et al. Triple negative breast cancer: outcome correlation with immunohistochemical detection of basal markers. Am J Surg Pathol 2010;34(7):956-964

17 Rao C, Shetty J, Prasad KH. Immunohistochemical profile and morphology in triple - negative breast cancers. J Clin Diagn Res 2013;7(7):1361-1365

18 Choi JE, Kang SH, Lee SJ, Bae YK. Androgen receptor expression predicts decreased survival in early stage triple-negative breast cancer. Ann Surg Oncol 2015;22(1):82-89
19 Ogawa Y, Hai E, Matsumoto K, et al. Androgen receptor expression in breast cancer: relationship with clinicopathological factors and biomarkers. Int J Clin Oncol 2008;13(5):431-435

20 Leidy J, Khan A, Kandil D. Basal-like breast cancer: update on clinicopathologic, immunohistochemical, and molecular features. Arch Pathol Lab Med 2014;138(1):37-43

21 Dent R, Trudeau M, Pritchard KI, et al. Triple-negative breast cancer: clinical features and patterns of recurrence. Clin Cancer Res 2007;13(15 Pt 1):4429-4434

22 D'Andrea AD. The Fanconi Anemia/BRCA signaling pathway: disruption in cisplatin-sensitive ovarian cancers. Cell Cycle 2003;2(4):290-292

23 Hirshfield KM, Ganesan S. Triple-negative breast cancer: molecular subtypes and targeted therapy. Curr Opin Obstet Gynecol 2014;26(1):34-40

24 Moe RE, Anderson BO. Androgens and androgen receptors: a clinically neglected sector in breast cancer biology. J Surg Oncol 2007;95(6):437-439

25 Lin FdeM, Pincerato KM, Bacchi CE, Baracat EC, Carvalho FM. Coordinated expression of oestrogen and androgen receptors in HER2-positive breast carcinomas: impact on proliferative activity. J Clin Pathol 2012;65(1):64-68

26 Mrklić I, Pogorelić Z, Capkun V, Tomić S. Expression of androgen receptors in triple negative breast carcinomas. Acta Histochem 2013;115(4):344-348 